\title{
Analysis of the Use of INTRANET LAN Innovation in Puslatbang KHAN
}

\author{
Ervina Yunita*, Henri Prianto Sinurat, Rati Sumanti \\ Puslatbang KHAN, Lembaga Administrasi Negara \\ Aceh Besar, Indonesia \\ *ervina.yunita@lan.go.id, henri.prianto@lan.go.id,rati.sumanti@lan.go.id
}

\begin{abstract}
The National Institute of Public Administration (NIPA) has launched the innovation of Intranet LAN in the early 2020. This innovation is an application that could be accessed by smartphone and computer. The Intranet LAN application has been used by the employees of NIPA as a presence tool during the pandemic of Covid-19. The application provides features which could be used by the employees to report their daily health, to track their locations and to input their work activities. As a part of NIPA's work unit, Puslatbang KHAN also uses the Intranet LAN to monitor employee's health and work activities. This research aims to analyze the use of Intranet LAN innovation in Puslatbang KHAN. The analysis was conducted based on a model from Delone-McLeane and Iivari with variables such as system quality, information quality, service quality and application impact. By using quantitative method with multiple linear regression, it can be concluded that the variables of system quality and service quality have an effect on the variable of application impact, while the variable of information quality has no effect on the variable of application impact. However, all of those variables have given an effect simultaneously on the application impact.
\end{abstract}

Keywords-Delone-McLeane and Iivari, Covid-19, online presence, multiple linear regression

\section{INTRODUCTION}

At the end of 2019, the world was shaken by the outbreak of the Corona Virus Disease 2019 (Covid-19). The outbreak also occurred Indonesia in early March 2020. Data from the World Health Organization (WHO) states in Indonesia the total number of confirmed cases of Covid-19 is 1528 and the total number of deaths is 136 cases in April $1^{\text {st } 2020 \text {. The }}$ Number has increased sharply, on April $11^{\text {th }} 2020$ shows that the total number of confirmed cases of Covid-19 is 3512, while the total number of deaths is 306 [1].

The increasing of Covid-19 patients in Indonesia has led the Government to adopt physical and social distancing policies to minimize transmission [2]. The purpose of physical distancing and social distancing is to regulate the physical distance among people, to reduce the virus spread. The implication is that meetings of a large number which can cause overcrowded of people should be avoided [3].
As the implementation of this policy, the National Institute of Public Administration (NIPA) has implemented physical and social distancing by imposing Work from Home (WFH) through Circular Number: 9/K.1/HKM.02.3/2020 concerning Work from Home during the Corona Disease Virus (Covid-19) pandemic for all of employee of NIPA since 19 March 2020.

In order to support the implementation of the WFH, since 30 March 2020 NIPA has launched the innovation INTRANET LAN as an online attendance tool. Larastri revealed that online attendance affects employee work discipline. There are 90 percent of employees who always arrive on time during work hours and there are 87 percent of employees who are afraid to come too late since their hour arrival will be seen immediately [4].

Apart from being used in government agencies, online attendance is used in schools. To discipline the government school teachers in division of Pendidikan Agama Islam (PAI) Cluster 3 Ahmad Yani, Sindangwangi District, Majalengka Regency, Android-based online attendance has been used. The result of research that most PAI teachers have been disciplined in time in carrying out their obligations [5]. Another research conducted that online attendance using smartphones is used to monitor student attendance by parents and teachers [6]. In line with this research, Faradilla also revealed that android-based online attendance makes it easier for teachers to attend students and calculate the number of student attendance [7].

In contrast to some of the research results above which focus on attendance reports and increased discipline, this study aims to determine health conditions, the location of employees and daily work output during WFH. This is to make it easier for leaders to control the implementation of WFH in NIPA environment. Of course, this goal is according to policy of implementing physical and social distancing which requires every employee to work from home. In fact, to minimize the transmission of Covid-19, during WFH all of employees must limit their activities outside their home.

This study differs from previous studies, by analyzing the use of online attendance Intranet LAN using Delon-McLean and Iivari merger model. Delon and McLean revealed that to analyze the impact of information system, six variables were used, there are system quality, information quality, service 
quality, usage, user satisfaction and net benefit [8]. Each of variables has several indicators to measure it.

Iivari conducted empirical testing of Delone-McLean Model, revealed that his overall findings are support the model, but some part still ambiguous as a causal explanatory model. Therefore, Iivari used five variables to analyze information system such as system quality, information quality, use, user satisfaction and individual impact [9]. Each of these variables also has several important indicators to measure it.

In this study, four variables were used and combine of Delone-McLean Model and Iivari. The variables and indicators used are:

\section{A. System Quality (Delone-McLeane Model)}

- Adaptability

- Availability

- Reliability

- Response time

- Usability

\section{B. Information Quality (Delone-McLeane Model)}

- Completeness

- Ease of understanding

- Personalization

- Relevance

- Security

\section{Service Quality (Delone-McLeane Model)}

- Assurance

- Responsiveness

- Empathy

\section{Individual Impact (Iivari)}

- Accomplish tasks more quickly.

- Improve job performance.

- Useful in job

\section{MethodOLOGY}

This approach in this study is quantitative method with multiple linear regression. The operational definition of the variables used in this study are Dependent Variable and Independent Variable. Data were collected with questionnaire instrument in the form of a close question. The questionnaire created in Likert scale to measure the attitudes, opinions and perceptions of a person or group of people about the use of the INTRANET LAN application. This research was conducted at
Puslatbang KHAN in Aceh Besar with a sample size equal to the population, 60 employees.

As for strengthening the above analysis, several hypotheses were compiled as follows:

\section{A. Hypothesis 1}

- Ho: B1 = 0 (There is no effect of System Quality on Application Impact)

- Ha: B1 > 0 (There is an influence of System Quality on Application Impact)

\section{B. Hypothesis 2}

- Ho: B2 = 0 (There is no influence of Information Quality on Application Impact)

- Ha: B2 > 0 (There is an influence of Information Quality on Application Impact)

\section{Hypothesis 3}

- Ho: B3 = 0 (There is no influence of Service Quality on Application Impact)

- Ha: B3 > 0 (There is an influence of Service Quality on Application Impact)

\section{Hypothesis 4}

- Ho: B4 = 0 (There is no influence of the variable system quality, information quality and service quality working simultaneously on the impact of the application)

- Ha: B4 > 0 (The influence of the variable system quality, information quality and service quality simultaneously on the impact of the application)

Based on the indicators above, this study will measure variable rate system quality, information quality, service quality, variable individual impact linear and multiple with the following equation:

Application impact $(\mathrm{Y})=$ system quality $(\mathrm{X} 1)+$ information quality $(\mathrm{X} 2)+$ service quality $(\mathrm{X} 3)+$ errors between variables $(\varepsilon)$.

\section{RESULTS AND DISCUSSION}

The distribution of questionnaires conducted online to 60 respondents, tested the validity to determine the validity or suitability of the questionnaire used.

\section{A. Validity Test}

The validity test carried out on variables X1 (System Quality), X2 (Information Quality), X3 (Service Quality), and $\mathrm{Y}$ (Application Impact) are as follows on table 1: 
TABLE I. VALIDITY TEST

\begin{tabular}{|c|c|c|c|c|}
\hline \multicolumn{1}{c|}{$\begin{array}{c}\text { Number } \\
\text { Instrument }\end{array}$} & X1 & $\mathbf{X 2}$ & $\mathbf{X 3}$ & Y \\
\hline 1 & 0.73 & 0.684 & 0.813 & 0.798 \\
\hline 2 & 0.692 & 0.763 & 0.874 & 0.853 \\
\hline 3 & 0.844 & 0.736 & 0.837 & 0.884 \\
\hline 4 & 0.828 & 0.765 & 0.741 & \\
\hline 5 & 0.679 & & & \\
\hline
\end{tabular}

The results of observations on the value of $\mathbf{r}_{\text {table }}$ obtained the value of the sample $\mathrm{N}=60$ of 0.254 . Referring to the results of the validity test, all instruments consisting of $\mathrm{X} 1, \mathrm{X} 2$, $\mathrm{X} 3$ and $\mathrm{Y}$ produce a value $\left(\mathbf{r}_{\text {count }}\right)>$ than the value of $\mathbf{r}_{\text {table. }}$. It can be concluded that all the instruments in this study are valid.

\section{B. Reliability Test}

Furthermore, a reliability test was carried out to see that all statements in this questionnaire were reliable or not. A variable is said to be reliable if Cronbach's Alpha $(\alpha)$ is greater than the value of 0.600 [10]. See table 2 below.

TABLE II. RELIABILITY TEST

\begin{tabular}{|l|l|}
\hline Variable & Cronbach's Alpha Value \\
\hline $\mathrm{X} 1$ & 0.809 \\
\hline $\mathrm{X} 2$ & 0.715 \\
\hline $\mathrm{X} 3$ & 0.831 \\
\hline $\mathrm{Y}$ & 0.800 \\
\hline
\end{tabular}

Based on the reliability test results from the table above, it can be seen that the variables $\mathrm{X} 1, \mathrm{X} 2, \mathrm{X} 3$ and $\mathrm{Y}$ are greater than 0.600 , so it can be concluded that the instrument in this study is very reliable.

\section{Normality Test}

After analyzing the research variables, it is necessary to test the normality to see whether the data distribution is normally distributed or not. See figure 1 below.

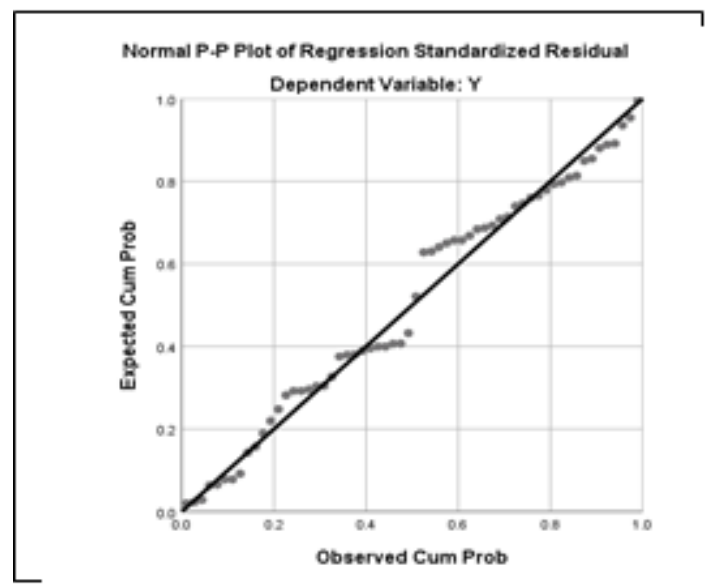

Fig. 1. Normality Test Graph.

The normality test graph above shows that the regression model in research with the object of the INTRANET LAN application research is feasible to use because it fulfils the assumption of normality. In the picture above, it can be seen that the distribution of plotting data (points) is on the line and follows the diagonal axis.

\section{Heteroscedasticity Test}

After fulfilling the normality test, then it will be seen whether the model avoids heteroscedasticity, because one of the good regression models is a model that avoids heteroscedasticity.

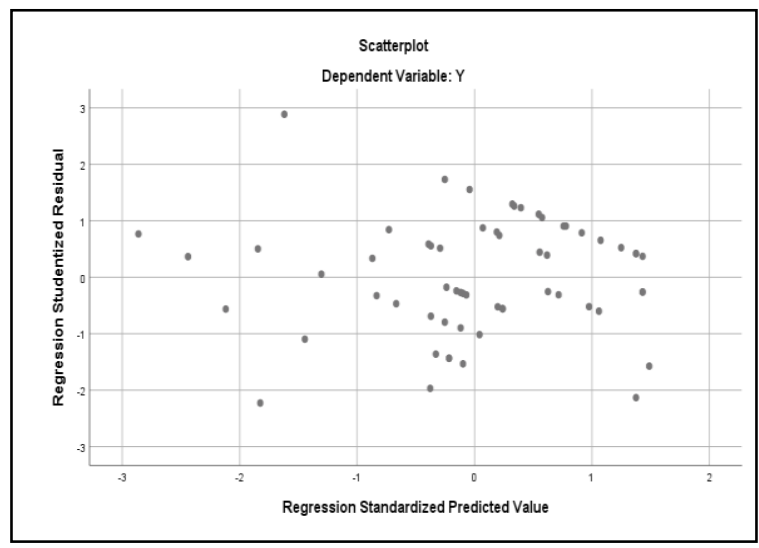

Fig. 2. Heteroscedasticity test graph.

From the picture above, it can be seen that the residual value spreads above and below the number 0 on the $\mathrm{Y}$ axis and does not form a clear or systematic pattern in the scatterplots image. Therefore, the object of research in this LAN intranet application is to avoid heteroscedasticity symptoms and is feasible in the study.

\section{E. Hypothesis Test}

As for seeing how much influence between the independent variable and the dependent variable, a Multiple Linear Regression Test were performed. See table 2 below.

TABLE III. COEFFICIENTS ${ }^{\mathrm{A}}$

\begin{tabular}{|c|c|c|c|c|c|}
\hline \multirow{2}{*}{ Model } & \multicolumn{2}{|c|}{$\begin{array}{c}\text { Unstandardized } \\
\text { Coefficients }\end{array}$} & $\begin{array}{c}\text { Standardized } \\
\text { Coefficients }\end{array}$ & $\boldsymbol{t}$ & Sig \\
\cline { 2 - 7 } & $\boldsymbol{B}$ & $\begin{array}{c}\text { Std. } \\
\text { Error }\end{array}$ & Beta & & \\
\hline Constant & 4.557 & 1.702 & & 2.678 & 0.01 \\
\hline Total_X1 & 0.126 & 0.109 & 0.171 & 1.155 & 0.253 \\
\hline Total_X2 & -0.072 & 0.157 & -0.085 & -0.459 & 0.648 \\
\hline Total_X3 & 0.404 & 0.122 & 0.574 & 3.318 & 0.002 \\
\hline
\end{tabular}

From the regression test table above, it can be interpreted as follows:

Hypothesis 1: Ha is accepted and Ho is rejected. This is calculated from the $\mathbf{t}$ test where $\mathbf{t}_{\text {count }}(1.155)>\mathbf{t}_{\text {table }}(0.678)$ so that it is evident that there is an effect of the system quality variable (X1) on the application impact variable $(\mathrm{Y})$. 
Hypothesis 2: Ha is rejected and Ho is accepted. This is calculated from the $\mathbf{t}$ test where $\mathbf{t}_{\text {count }}(-0.459)<\mathbf{t}_{\text {table }}(0.678)$ so it is evident that there is no influence of the information quality variable (X2) on the application impact variable (Y).

Hypothesis 3: $\mathrm{Ha}$ is accepted and Ho is rejected. This is calculated from the $\mathbf{t}$ test where $\mathbf{t}_{\text {count }}(3.318)>\mathbf{t}_{\text {table }}(0.678)$ so that it is evident that there is an influence of the service quality variable $(\mathrm{X} 3)$ on the application impact variable $(\mathrm{Y})$.

\section{F. Simultant Test $(f$-test $)$}

Hypothesis 4: Ha is accepted, and Ho is rejected. This is calculated from the $\mathbf{F}$ test where $\mathbf{F}_{\text {count }}(12.179)>\mathbf{F}_{\text {table }}(2.77)$ so that it is evident that the variables in this study (system quality, information quality and service quality) simultaneously have an influence on the application impact variable (Y).

The regression results can be written in the following equation:

Application Impact $(\mathrm{Y})=4.557+0.126$ System Quality (X1) - 0.072 Information Quality (X2) + 0.404 Service Quality $(\mathrm{X} 3)+\varepsilon$

See table 4 below.

TABLE IV. MODEL SUMMARY

\begin{tabular}{|c|c|c|c|}
\hline $\mathbf{R}$ & $\begin{array}{c}\text { R } \\
\text { Square }\end{array}$ & $\begin{array}{c}\text { Adjusted } \\
\text { R Square }\end{array}$ & $\begin{array}{c}\text { Standard Error of } \\
\text { the Estimate }\end{array}$ \\
\hline $0.628^{\mathrm{a}}$ & 0.395 & 0.362 & 1.626 \\
\hline \multicolumn{4}{|c}{${ }^{\mathrm{a}}$ Predictors: (Constant), Total_X3, Total_X1, Total_X2 } \\
\multicolumn{3}{|c}{ b. Dependent Variable: $\mathrm{Y}$}
\end{tabular}

The Adjusted R square column value of 0.362 means that $36 \%$ of the impact variable of LAN Intranet Application (Y) can be explained from the variables of system quality (X1), information quality (X2) and service quality (X3), while the rest can be explained by other variables.

\section{CONCLUSION}

From the research entitled Analysis of the Use of LAN Intranet Innovations in Puslatbang KHAN, the following conclusions are obtained:

- There is an impact of variable System Quality on the dependent variable application impact. If the quality of the system increases, the impact of the LAN Intranet application will increase because it has a positive effect. Application Intranet LAN easy to learn, downloaded easily, reliable and connected quickly. So that it is useful for users in terms of recapitulating health, attendance, and employee presence more quickly. This application also makes it easier for employees to prepare daily work reports.
- The existence of the information generated by the LAN Intranet Application has no effect on the impact of the application. The existence of complete, private and easy to understand user manual and personal information security guarantee, do not affect the results of health recapitulation, attendance, employee presence more quickly, and on the preparation of daily work reports.

- There is an influence on the service quality variable on the application impact variable. Because of the quality of services is increasing with the service status of the health and location of employees within an application that can accommodate the Task Force for Covid-19 in NIPA to make a policy.

- There is a simultaneous influence of system quality variables, information quality and service quality on the application impact variables. However, there are also some variables not included in this study that can affect the impact of the application.

As for the suggestion of this study is to improve the quality of the system such as adding features that can access the delivery of health consulting information so that it can increase the quality and quantity of information. Furthermore, there needs accuracy improvement regarding employee's location.

\section{REFERENCES}

[1] World Heatlh Organization, "Coronavirus Disease 2019 (Covid-19) Situation Report - 82," JAMA, vol. 323, no. 12, p. 1122, Mar. 2020.

[2] A. Kresna and J. Ahyar, "Pengaruh Physical Distancing dan Social Distancing Terhadap Kesehatan Dalam Pendekatan Linguistik," J. Syntax Transform., vol. 1, no. 4, pp. 14-19, 2020.

[3] N.R. Yunus and A. Rezki, "Kebijakan Pemberlakuan Lock Down Sebagai Antisipasi Penyebaran Corona Virus Covid-19," SALAM J. Sos. dan Budaya Syar-i, vol. 7, no. 3, pp. 227-238, Mar. 2020.

[4] D. Larasatri, "Korelasi Implementasi Sistem Presensi Sidik Jari (Fingerprint) Online dan Kedisiplinan Terhadap Perubahan Perilaku Kerja Pegawai,” J. Strateg. dan Bisnis, vol. 4, no. 1, pp. 1-20, 2016.

[5] Y. Mulyani, "Penerapan Absensi Online Berbasis Android Pada Peningkatan Kedisiplinan dan Kinerja Guru Pegawai Negeri Sipil Pada Bidang PAI," J. Educ. FKIP UNMA, vol. 6, no. 1, pp. 205-209, 2020.

[6] A. Sumarudin, W. Permana, A. Suheryadi, K. Maulana, and N. Ibrahim, "Penerapan Sistem Absensi Sekolah Menggunakan Fingerprint Terintegrasi Dengan Smartphone Android," J. Appl. INFORMATICS Comput., vol. 3, no. 1, pp. 18-22, May 2019.

[7] D. Faradilla and Z. Ardian, "Aplikasi Absensi Siswa Untuk Kemudahan Informasi Antara Pihak Sekolah dan Orang Tua pada Sekolah Dasar Negeri 3 Banda Aceh Berbasis Android," J. INFORMATICS Comput. Sci., vol. 4, no. 2, p. 189, Dec. 2019.

[8] W.H. DeLone and E.R. McLean, "The DeLone and McLean Model of Information Systems Success: A Ten-Year Update,” J. Manag. Inf. Syst., vol. 19, no. 4, pp. 9-30, Apr. 2003.

[9] J. Iivari, "An empirical test of the DeLone-McLean model of information system success," ACM SIGMIS Database DATABASE Adv. Inf. Syst., vol. 36, no. 2, pp. 8-27, Jun. 2005.

[10] I. Ghozali, “Aplikasi Analisi Multivariate Dengan Program SPSS 19," Ed. kelima semarang Bandan Pnb. Univ. Diponegoro, 2011. 